\title{
KEANEKARAGAMAN JENIS BURUNG DI LAHAN BASAH WAY PEGADUNGAN DESA RAJAWALI KECAMATAN BANDAR SURABAYA KABUPATEN LAMPUNG TENGAH
}

\section{(WETLAND BIRDS DIVERSITY AT WAY PEGADUNGAN RAJAWALI VILLAGE BANDAR SURABAYA DISTRICT CENTRAL LAMPUNG REGENCY)}

\author{
Badia Roy Ricardo Nababan, Agus Setiawan, dan Nuning Nurcahyani \\ Jurusan Kehutanan, Fakultas Pertanian, Universitas Lampung \\ J1. Prof. Soemantri Brojonegoro No. 1 Gedong Meneng, Bandar Lampung \\ Email : rnababan31@gmail.com
}

\begin{abstract}
ABSTRAK
Lahan basah Way Pegadungan merupakan lahan basah yang memiliki perbedaan penutupan komunitas antara kedua sempadan sungai. Salah satu sempadan dialihfungsikan menjadi persawahan, sedangkan sisi lainnya masih alami. Untuk mengetahui perbedaan keanekaragaman jenis burung di kedua komunitas tersebut dilakukan penelitian dengan metode titik hitung (IPA) dan line transect. Pengamatan dilakukan dengan diam pada titik hitung dan mencatat burung yang dijumpai. Pada masing-masing komunitas diambil 6 titik hitung dengan masing-masing 3 hari pengamatan. Hasil penelitian menunjukkan terdapat 41 spesies burung yang terdiri atas 17 famili dengan total individu 796 pada lahan basah persawahan dan 46 spesies burung dengan total individu 655 individu yang terdiri dari 17 famili pada lahan basah alami. Lahan basah alami memiliki indeks keanekaragaman sebesar 3,44 dengan indeks kesamarataan sebesar 0,90, nilai ini lebih tinggi dibandingkan lahan basah yang telah beralih fungsi menjadi persawahan dengan indeks keanekaragaman sebesar 2,91 serta dalam kondisi yang stabil dengan indeks kesamarataan sebesar 0,78. Kedua komunitas pada lahan basah ini memiliki kesamaan spesies mendekati identik (IS=1) dengan indeks kesamaan sebesar 0,73 .
\end{abstract}

Kata kunci: burung, keanekaragaman jenis, lahan basah, Way Pegadungan

\section{ABSTRACT}

Way Pegadungan wetlands is a wetland closure difference between the two riparian communities. One of the wetlands is converted into paddies fields, while the other is a natural wetland which are still overgrown with trees. To determine diversity differences in bird species between two wetlands research communities, the point count method (IPA) and line transects were used. Observations made by the stationary point count and record the birds found. Each community was taken 6 points count and observed for 3 days. Research encountered 41 species of birds included in the 17 families with a total of 796 individual in paddies fields and 46 birds species with total of 655 individuals from 17 families of individuals in natural wetlands. Natural wetlands diversity index was 3.44 with equality index of 0.90, this value is higher than the wetlands changed into paddies fields with a diversity index of 2.91, and in a stable condition with equality index of 0.78. Both wetlands communities have the same identical species approach $(I S=1)$ with a similarity index of 0.73 .

Key words: birds, diversity, wetlands, Way Pegadungan 


\section{PENDAHULUAN}

Beberapa bagian habitat burung dapat berfungsi sebagai tempat untuk mencari makan, minum, istirahat, dan berkembang biak. Salah satu tipe habitat adalah lahan basah. Indonesia memiliki areal lahan basah yang cukup luas. Salah satu lahan basah yang ada di Provinsi Lampung yang menjadi habitat burung terdapat di Desa Rajawali, Kecamatan Bandar Surabaya, Kabupaten Lampung Tengah. Lahan basah tersebut berada di sepanjang Sungai Way Pegadungan dan sudah banyak yang berubah menjadi persawahan.

Populasi burung pada lahan basah menurun seiring dengan bertambahnya aktivitas manusia. Kondisi ekosistem alami yang terus mengalami tekanan menyebabkan perlu segera dilakukannya upaya-upaya konservasi (Holmes dan Rombang, 2001). Data dan informasi yang sedikit mengenai jumlah jenis, populasi serta kebiasaan hidup mempersulit dalam merumuskan suatu kegiatan konservasi sehingga adanya perumusan masalah tentang tingkat keanekaragaman jenis burung di lahan basah Way Pegadungan Desa Rajawali Kecamatan Bandar Surabaya Kabupaten Lampung Tengah. Selanjutnya, adakah perbedaan keanekaragaman jenis burung antara lahan basah yang masih alami dan lahan basah persawahan di lahan basah Way Pegadungan Desa Rajawali Kecamatan Bandar Surabaya Kabupaten Lampung Tengah. Oleh karena itu dilakukan penelitian mengenai keanekaragaman jenis burung di Desa Rajawali, sehingga diperoleh data keanekaragaman jenis burung yang diperlukan dalam upaya perlindungan dan pelestarian burung beserta habitatnya.

Tujuan dari penilitian ini yaitu untuk mengetahui keanekaragaman jenis burung berdasarkan indeks keanekaragaman Shannon-Wienner dan indeks kesamarataan di lahan basah Way Pegadungan Desa Rajawali Kecamatan Bandar Surabaya Kabupaten Lampung Tengah. Selain itu penelitian bertujuan untuk membandingkan keanekaragaman jenis burung antara lahan basah yang alami dengan lahan basah persawahan berdasarkan indeks keanekaragaman Shannon-Wienner dan indeks kesamarataan di lahan basah Way Pegadungan Desa Rajawali Kecamatan Bandar Surabaya Kabupaten Lampung Tengah.

Manfaat penelitian ini yaitu sebagai sumber informasi ilmiah untuk peneliti lain tentang keanekaragaman burung di lahan basah Way Pegadungan Desa Rajawali Kecamatan Bandar Surabaya Kabupaten Lampung Tengah. Hasil penelitian menjadi dasar ilmiah bagi Pemerintah Kabupaten Lampung Tengah dalam rangka pelestarian dan perlindungan burung di lahan basah Way Pegadungan Desa Rajawali Kecamatan Bandar Surabaya Kabupaten Lampung Tengah

\section{METODE PENELITIAN}

\section{Lokasi dan Waktu Penelitian}

Pengamatan dilakukan pada habitat lahan basah yang telah menjadi persawahan dan lahan basah yang relatif masih alami (Gambar 1). Penelitian dilakukan pada bulan April 2014 di lahan basah Way Pegadungan, Desa Rajawali, Kecamatan Bandar Surabaya, Kabupaten Lampung Tengah. Pengamatan dilakukan pada pagi hari (pukul $06.00-08.00$ WIB) dan pada sore hari (pukul $16.00-18.00 \mathrm{WIB}$ ). 


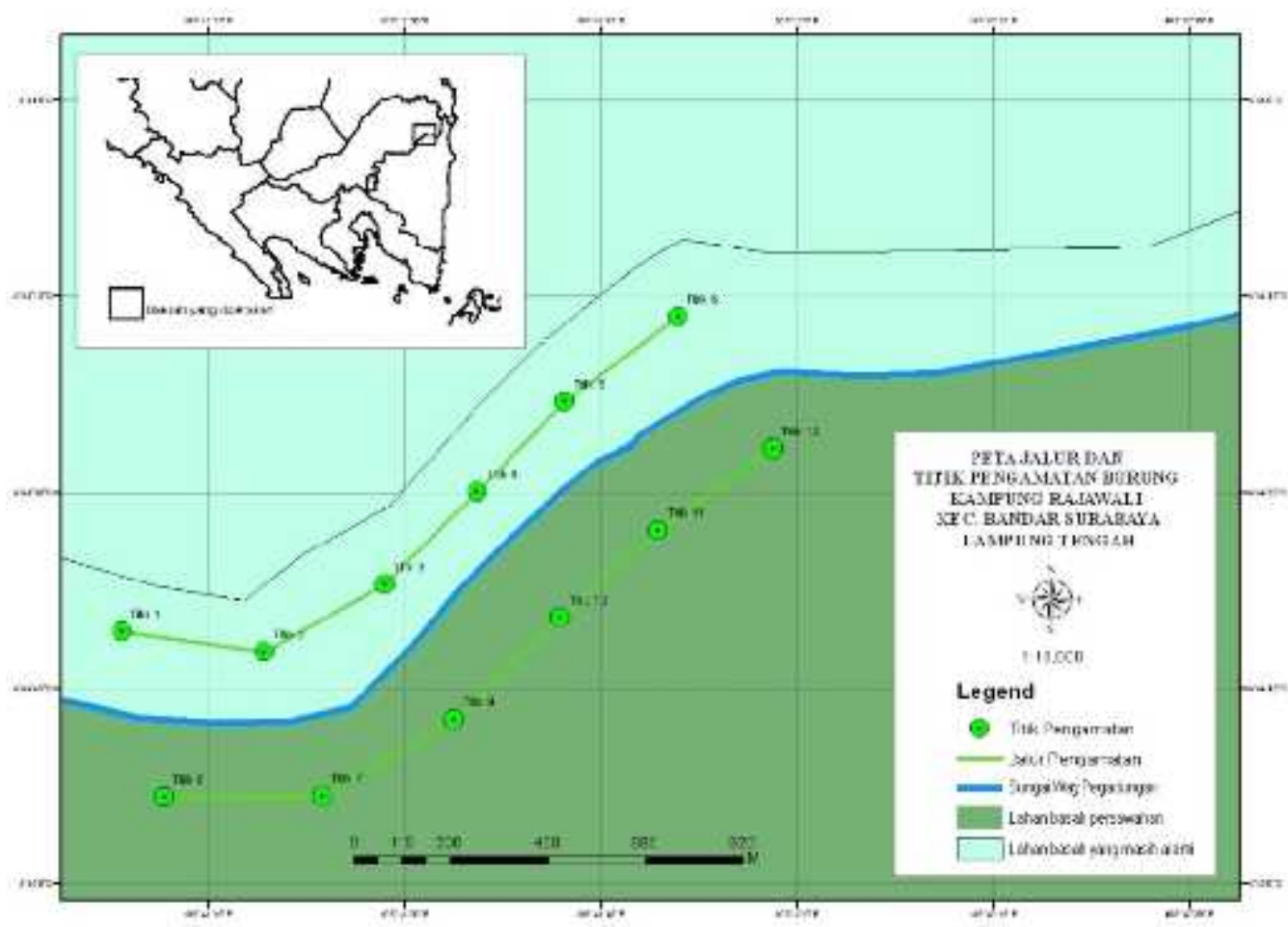

Gambar 1. Peta lokasi penelitian keanekaragaman jenis burung di lahan basah Way Pegadungan, Desa Rajawali, Kecamatan Bandar Surabaya, Kabupaten Lampung Tengah.

\section{Bahan dan Alat}

Bahan yang digunakan adalah spesies burung yang ada di dalam kawasan. Alat yang digunakan dalam penelitian ini adalah teropong binokuler, kamera digital, Global Positioning System (GPS) dan kompas, jam tangan, rol meter, alat tulis dan buku identifikasi spesies burung "Seri Buku Panduan Lapangan Burung-Burung di Sumatera, Jawa, Bali, dan Kalimantan" (Mac Kinnon, Philipps, dan Van Balen, 2010).

\section{Metode Penelitian}

Penelitian menggunakan metode kombinasi antara metode titik hitung (Point Count) atau IPA (Index Point Abundance) dan line transect (Bibby, Jones dan Marsden, 2000). Letak masing-masing transek berada pada sempadan sungai, sejajar dengan arah sungai.

Pelaksanaan pengamatan dilakukan dengan cara diam pada titik yang telah ditentukan kemudian mencatat burung yang dijumpai. Data yang dicatat yaitu jenis dan jumlah. Pengamatan dilakukan pada enam titik hitung/stasiun pengamatan. Seluruh titik hitung pada masing-masing jalur pengamatan berada dalam jalur transek yang panjangnya \pm 1.800 meter sehingga jarak antar titik pengamatan adalah sekitar \pm 300 meter. Di setiap titik hitung, pengamatan dilakukan dengan radius 50 meter dengan lama pengamatan 20 menit, kemudian berjalan ke titik pengamatan selanjutnya.

Kondisi umum areal pengamatan diamati dengan metode rapid assessment untuk mendapatkan gambaran secara umum tipe vegetasi di tempat ditemukannya keberadaan burung. Aspek yang diamati meliputi naungan (cover) dan tempat bersarang (nesting site). Penentuan nilai keanekaragaman jenis dilakukan dengan menggunakan rumus berikut (Odum (1993), dikutip oleh Sulistyadi (2010)): 


$$
H^{\prime}=-\sum P i \ln (P i), \operatorname{dimana} P i=(n i / N)
$$

Keterangan :

$H^{\prime}=$ Indeks keanekaragaman Shannon-Wienner

$n i=$ Jumlah individu jenis ke-i

$N=$ Jumlah individu seluruh jenis

Kriteria nilai indeks keanekaragaman Shannon - Wiener $\left(H^{\prime}\right)$ adalah sebagai berikut:

$H^{\prime}<1$ : keanekaragaman rendah,

$1<H^{\prime} \unlhd$ : keanekaragaman sedang,

H'> 3 : keanekaragaman tinggi.

Indeks kesamarataan digunakan untuk mengetahui kesamarataan setiap spesies dalam setiap komunitas yang dijumpai. Indeks kesamarataan dikutip oleh Kesuma (2013), diperoleh dengan menggunakan rumus sebagai berikut :

Keterangan :

$$
J=H^{\prime} / H \max \text { atau } J=-\Sigma P i \ln (P i) / \ln (S)
$$

$J=$ Indeks kesamarataan

$S=$ Jumlah jenis

Kriteria indeks kesamarataan $(J)$ menurut Daget (1976), dikutip oleh Pergola (2013), adalah sebagai berikut

$$
\begin{array}{ll}
0<J \leq 0,5 & : \text { Komunitas tertekan } \\
0,5<J \leq 0,75 & : \text { Komunitas labil } \\
0,75<J \leq 1 & : \text { Komunitas stabil. }
\end{array}
$$

Kesamaan jenis burung di kedua lahan basah dilihat dengan indeks kesamaan jenis. Indeks kesamaan diperlukan untuk mengetahui tingkat kesamaan komposisi spesies antar dua habitat, dihitung dengan menggunakan rumus (Odum, 1993).

$$
\mathrm{IS}=2 \mathrm{C} /(\mathrm{A}+\mathrm{B})
$$

Keterangan: $\quad \mathrm{A}=$ jumlah spesies yang dijumpai pada komunitas 1 ,

$\mathrm{B}=$ jumlah spesies yang dijumpai pada komunitas 2 ,

$\mathrm{C}=$ jumlah spesies yang sama pada kedua komunitas.

Analisis deskriptif digunakan dalam menggambarkan habitat yang digunakan oleh burung, dan diuraikan berdasarkan hasil pengamatan yang dilakukan.

\section{HASIL DAN PEMBAHASAN}

\section{Keanekaragaman Jenis Burung di Lahan Basah Way Pegadungan}

Berdasarkan penelitian yang telah dilakukan selama 6 hari penelitian ditemukan 20 famili burung yang terdiri atas 56 spesies burung dengan total 1.451 individu. Pada kedua komunitas lahan basah tersebut masing-masing terdapat 17 famili burung dengan 41 spesies burung yangberjumlah 796 individu lahan basah yang menjadi persawahan dan pada lahan basah yang masih alami terdapat 46 spesies burung dengan total 655 individu. Perbandingan individu tiap famili disajikan pada Gambar 2.

\section{Indeks Keanekaragaman Jenis dan Indeks Kesamarataan}

Berdasarkan hasil penelitian yang dilakukan di lahan basah Way Pegadungan diperoleh keanekaragaman jenis burung yang berbeda antara dua tipe komunitas lahan basah 
yang ada (Tabel 1). Berdasarkan data tersebut, pada lahan basah yang masih alami dengan banyak pepohonan memiliki tingkat keanekaragaman jenis 3,44 lebih tinggi dibandingkan lahan basah yang menjadi sawah yang memiliki tingkat keanekaragaman jenis 2, 91 .

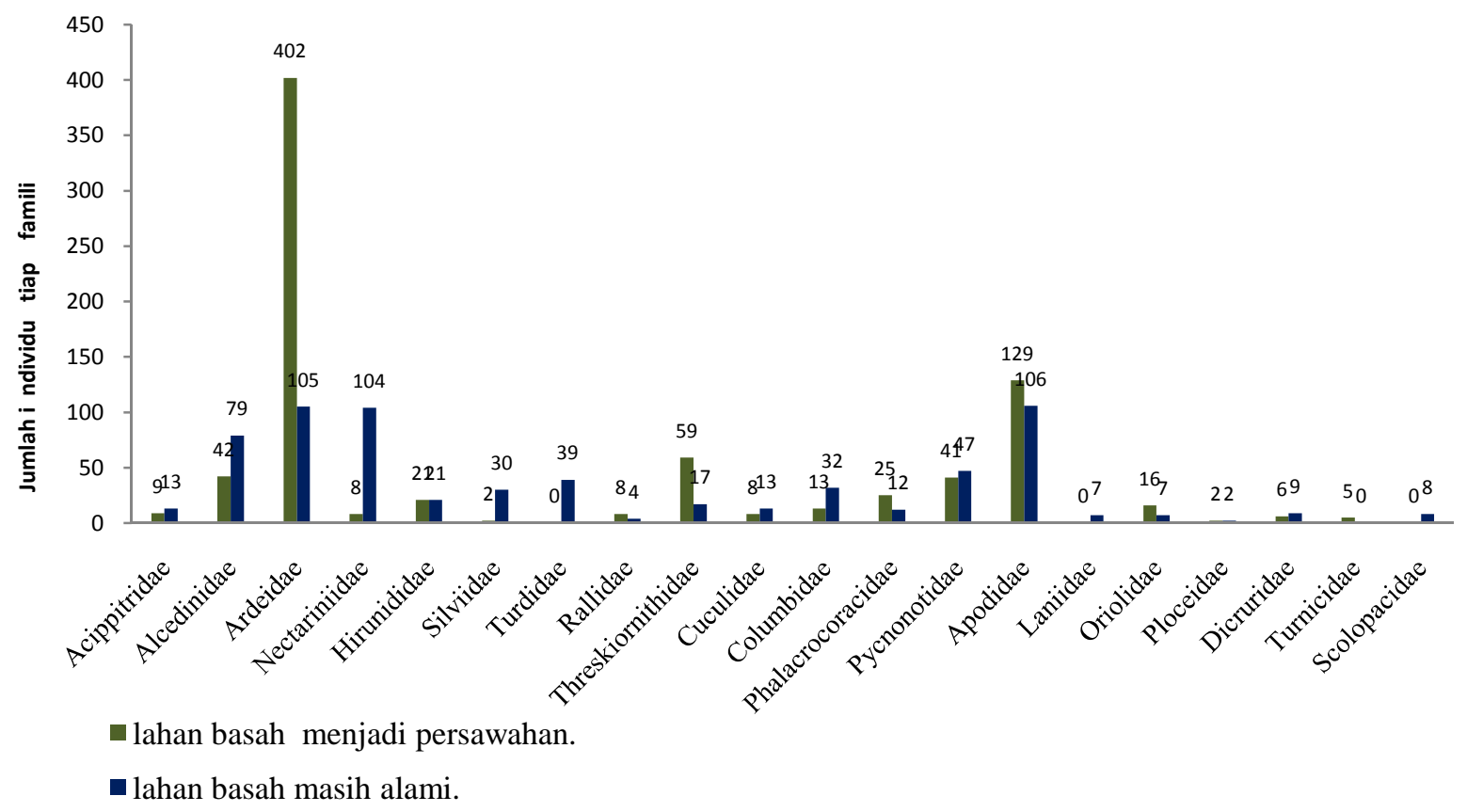

Gambar 2. Perbedaan jumlah individu tiap famili burung-burung di dua komunitas lahan basah yang berbeda pada Way Pegadungan.

\section{Indeks kesamaan spesies (Similarity index)}

Kedua lahan basah tersebut memiliki indeks kesamaan yaitu 0,73 , yang artinya dalam kedua habitat ini banyak terdapat spesies yang sama dengan kata lain $73 \%$ memiliki kesamaaan spesies mendekati identik. Tingginya nilai indeks kesamaan disebabkan kedua komunitas berdekatan, hanya dipisahkan oleh sungai sehingga burung dapat berpindah dan menempati kedua komunitas lahan basah.

Tabel 1. Indeks keanekaragaman dan indeks kesemarataan burung di lahan basah Sungai Way Pegadungan Kabupaten Lampung Tengah

\begin{tabular}{|c|c|c|c|c|}
\hline $\begin{array}{l}\text { Tipe komunitas } \\
\text { lahan basah }\end{array}$ & $\begin{array}{c}\text { Jumlah } \\
\text { spesies }\end{array}$ & Jumlah famili & $\begin{array}{c}\text { Indeks } \\
\text { keanekaragaman }\end{array}$ & $\begin{array}{c}\text { Indeks } \\
\text { kesamarataan }\end{array}$ \\
\hline $\begin{array}{l}\text { Lahan basah } \\
\text { menjadi sawah }\end{array}$ & 41 & 17 & $2,91 * *$ & $0,78^{* * * *}$ \\
\hline $\begin{array}{l}\text { Lahan basah } \\
\text { masih alami }\end{array}$ & 46 & 19 & $3,44 *$ & $0,9^{* * * *}$ \\
\hline $\begin{array}{ll}\text { Keterangan: } & * \\
& * * \\
& * * *\end{array}$ & $\begin{array}{l}=\text { Indeks } \\
=\text { Indeks } \\
=\text { Indeks }\end{array}$ & $\begin{array}{l}\text { karagaman tingg } \\
\text { karagaman sedai } \\
\text { narataan menunj }\end{array}$ & $\begin{array}{l}\text { g } \\
\text { kkan komunitas stab }\end{array}$ & \\
\hline
\end{tabular}




\section{Penyebaran jenis Burung Berdasarkan Tipe Habitat}

Berdasarkan hasil pengamatan, dari total 56 spesies yang ditemukan, terdapat 10 jenis (18\%) burung yang hanya dijumpai pada komunitas lahan basah yang menjadi persawahan dan komunitas lahan basah yang alami hanya dijumpai 15 jenis burung (27\%), sedangkan jenis burung yang dijumpai pada kedua tipe komunitas yaitu 31 jenis (55\%) (Gambar 3).

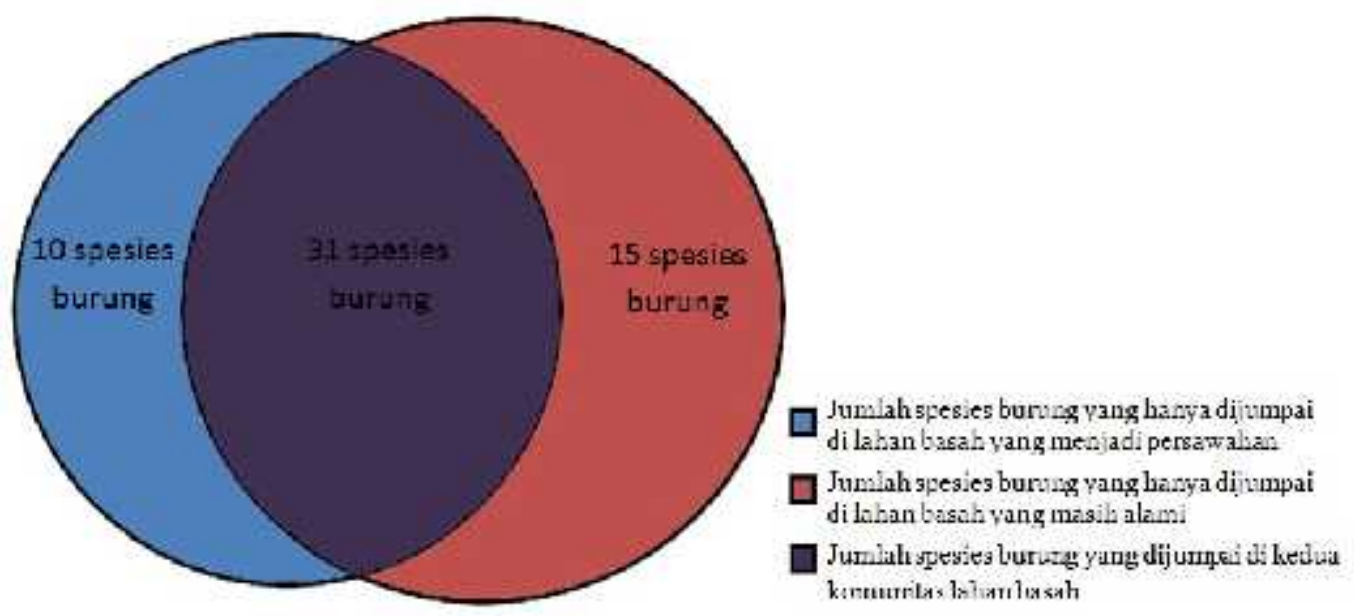

Gambar 3. Perbandingan jenis burung yang menempati dua tipe komunitas lahan basah yang terdata saat pengamatan di lahan basah Way Pegadungan.

Jenis burung yang dijumpai pada kedua tipe komunitas yaitu walet sarang hitam (Collocalia maxima), kuntul kecil (Egretta garzetta), kuntul karang (Egretta sacra), cucak kutilang (Pycnonotus aurigaster), blekok sawah (Ardeola speciosa) dan belibis kembang (Dendrocygna arcuata). Tingginya jumlah spesies yang dapat hidup di suatu komunitas menunjukkan bahwa komunitas tersebut memberikan peranan baik bagi keberadaan burung untuk mencari pakan, bersarang, dan berlindung dari predator (Rohiyan, 2013).

Beberapa jenis burung seperti spesies burung dari famili Nectariniidae dan Pycnonotidae sebagai contoh burung madu sriganti (Nectarinia jugularis) dan merbah cerukcuk (Pycnonotus goiavier) memilih habitat dengan pepohonan yang menghasilkan nektar atau buah sebagai pakan.

Jenis burung kuntul kecil, kuntul karang, dan blekok sawah merupakan jenis burung yang dijumpai di lahan basah persawahan sebab jenis burung ini mencari pakan pada lahan basah dengan kedalaman 0-40 cm, sedangkan burung walet sarang hitam, cucak kutilang, dan pijantung kecil merupakan jenis burung yang dijumpai di lahan basah alami dengan banyak pepohonan yang mempunyai buah dan bunga. Jenis burung penghisap nektar dan pemakan buah yang sering dijumpai pada pepohonan penghasil buah dan bunga (Surya, 2013) 
Tabel 2. Sebaran spesies burung pada masing-masing tipe komunitas di lahan basah Way Pegadungan, Desa Rajawali, Kecamatan Bandar Surabaya, Kabupaten Lampung Tengah.

\begin{tabular}{|c|c|c|c|c|}
\hline No & Nama Spesies & Famili & LBS & LBA \\
\hline 1 & Elang Laut Perut Putih* II LC & Acippitridae & 4 & 4 \\
\hline 2 & Elang Ikan Kepala Kelabu* II NT & Acippitridae & 0 & 5 \\
\hline 3 & Elang Ikan Kecil* & Acippitridae & 5 & 1 \\
\hline 4 & Elang Bondol* II LC & Acippitridae & 0 & 3 \\
\hline 5 & Layang Layang Batu ${ }^{\mathrm{LC}}$ & Hirunididae & 21 & 21 \\
\hline 6 & Cekakak Belukar* LC & Alcedinidae & 8 & 10 \\
\hline 7 & Raja Udang Biru* LC & Alcedinidae & 2 & 4 \\
\hline 8 & Raja Udang Erasia* & Alcedinidae & 4 & 8 \\
\hline 9 & Raja Udang Meninting* LC & Alcedinidae & 14 & 7 \\
\hline 10 & Cekakak Sungai* LC & Alcedinidae & 11 & 26 \\
\hline 11 & Cekakak Batu* LC & Alcedinidae & 3 & 0 \\
\hline 12 & Pekakak Emas* & Alcedinidae & 0 & 24 \\
\hline 13 & Kuntul Kecil* LC & Ardeidae & 134 & 23 \\
\hline 14 & Kuntul Karang* LC mn & Ardeidae & 97 & 8 \\
\hline 15 & Kuntul Besar* LC mn & Ardeidae & 13 & 6 \\
\hline 16 & Kuntul Kerbau* LC mn & Ardeidae & 12 & 11 \\
\hline 17 & Kokokan Laut ${ }^{\mathrm{LC}}$ & Ardeidae & 2 & 6 \\
\hline 18 & Kowak Malam Merah* LC & Ardeidae & 4 & 3 \\
\hline 19 & Kareo Padi LC & Ardeidae & 6 & 9 \\
\hline 20 & Bambangan Merah & Ardeidae & 12 & 8 \\
\hline 21 & Cangak Merah LC mn & Ardeidae & 8 & 4 \\
\hline 22 & Tikusan Kaki Kelabu & Ardeidae & 0 & 3 \\
\hline 23 & Tikusan Merah ${ }^{\text {LC }}$ & Ardeidae & 17 & 0 \\
\hline 24 & Kuntul Cina* V mn & Ardeidae & 6 & 0 \\
\hline 25 & Blekok Sawah LC & Ardeidae & 87 & 24 \\
\hline 26 & Cangak Abu LC mn & Ardeidae & 4 & 0 \\
\hline 27 & Burung Madu Sriganti* LC & Nectariniidae & 8 & 24 \\
\hline 28 & Pijantung Kecil* & Nectariniidae & 0 & 35 \\
\hline 29 & Burung Madu Kelapa* & Nectariniidae & 0 & 31 \\
\hline 30 & Burung Madu Belukar* & Nectariniidae & 0 & 14 \\
\hline 31 & Perenjak Rawa LC & Silviidae & 2 & 17 \\
\hline 32 & Perenjak ${ }^{\mathrm{LC}}$ & Silviidae & 0 & 13 \\
\hline 33 & Kucica Kampung LC & Turdidae & 0 & 16 \\
\hline 34 & Kucica Hutan LC & Turdidae & 0 & 23 \\
\hline 35 & Mandar Batu LC mn & Rallidae & 4 & 2 \\
\hline 36 & Mandar Padi Sintar LC & Rallidae & 4 & 2 \\
\hline 37 & Belibis Kembang LC & Threskiornithidae & 40 & 17 \\
\hline 38 & Belibis Batu ${ }^{\text {LC }}$ & Threskiornithidae & 19 & 0 \\
\hline 39 & Butbut Tegarop $\mathrm{v}$ & Cuculidae & 0 & 6 \\
\hline 40 & But But Alang Alang LC & Cuculidae & 8 & 7 \\
\hline 41 & Terkukur ${ }^{\mathrm{LC}}$ & Columbidae & 10 & 22 \\
\hline 42 & Perkutut ${ }^{\mathrm{LC}}$ & Columbidae & 3 & 10 \\
\hline 43 & Pecuk Padi Hitam LC mn & Phalacrocoracidae & 0 & 12 \\
\hline 44 & Pecuk Padi Kecil LC mn & Phalacrocoracidae & 25 & 0 \\
\hline 45 & Cucak Kuricang LC & Pycnonotidae & 2 & 0 \\
\hline
\end{tabular}


Tabel 2 (lanjutan)

\begin{tabular}{rllrr}
\hline No & Nama Spesies & Famili & LBS & \multicolumn{1}{c}{ LBA } \\
\hline 46 & Cucak Kelabu NT & Pycnonotidae & 0 & 9 \\
47 & Cucak Rawa II V & Pycnonotidae & 9 & 0 \\
48 & Cucak Kutilang LC & Pycnonotidae & 20 & 23 \\
49 & Merbah Cerukcuk LC & Pycnonotidae & 10 & 15 \\
50 & Walet Sarang Hitam LC & Apodidae & 129 & 106 \\
51 & Bentet Kelabu LC & Laniidae & 0 & 7 \\
52 & Gagak Hutan LC & Oriolidae & 16 & 7 \\
53 & Bondol Haji LC & Ploceidae & 2 & 0 \\
54 & Srigunting Hutan & Dicruridae & 6 & 9 \\
55 & Gemak Tegalan LC & Turnicidae & 5 & 0 \\
56 & Trinil Kaki Hijau LC mr & Scolopacidae & 0 & 8 \\
\hline
\end{tabular}

Ket: LBS= Lahan Basah Sawah; LBA= Lahan Basah Alami; * = Satwa dilindungi menurut $\mathrm{PP}$ no. 7/1999; II= Appendix 2; LC= Least Concern; NT= Near Threatened; $\mathrm{V}=$ Vulnerable;

\section{Peranan Habitat}

Beberapa spesies burung bergantung pada lahan basah dengan memanfaatkan semak dan tumbuhan air untuk berlindung dari serangan predator. Lokasi pengamatan lainnya berupa lahan basah yang didominasi pepohonan yang cukup rapat. Pada lahan basah ini terdapat pepohonan penghasil nektar dan buah seperti bungur lilin (Lagerstroemia speciosa) dan loa (Ficus racemosa) yang menjadi pakan burung. Jenis-jenis tumbuhan yang teridentifikasi disajikan pada Tabel 3.

Pada lokasi lahan basah persawahan terdapat 3 sarang yang merupakan sarang gemak tegalan (Turnix sylvatica), 2 sarang yang diduga merupakan sarang burung madu sriganti (Nectarinia jugularis), 2 sarang yang diduga merupakan sarang gagak hutan (Corvus enca), serta 9 sarang yang diduga merupakan sarang spesies bambangan merah (Ixobrychus cinnamomerus).

Sarang burung spesies gemak tegalan (Turnix sylvatica) dan bambangan merah (Ixobrychus cinnamomerus) terdapat pada semak semak sawah dan rerumputan, seperti tumbuhan capo air (Polygonum pulchrum) alang alang (Imperata cylindrica) dan rumput alas (Sacciolepis sp), sedangkan sarang burung madu sriganti (Nectarinia jugularis) ditemukan pada pohon gelam (Eugenia sp.) dan sarang gagak hutan (Corvus enca) pada pohon palem (Livistona sp.).

Pada lahan basah dengan banyak pepohonan terdapat 3 sarang yang diduga merupakan sarang burung madu sriganti (Nectarinia jugularis), 3 sarang yang diduga merupakan sarang burung pijantung kecil (Arachnotera longirostra), dan 1 sarang yang diduga merupakan sarang burung elang ikan kepala kelabu (Ichthyophaga ichthyyaetus). Banyaknya sarang yang ditemukan di lokasi penelitian menunjukkan bahwa lahan basah Way Pegadungan merupakan salah satu habitat dalam pelestarian keanekaragaman jenis burung. 
Tabel 3. Jenis jenis tumbuhan yang teridentifikasi pada lahan basah Way Pegadungan, Desa Rajawali, Kecamatan Bandar Surabaya, Kabupaten Lampung Tengah.

\begin{tabular}{llcc}
\hline Jenis tumbuhan & \multicolumn{1}{c}{ Nama ilmiah } & $\begin{array}{c}\text { Lahan basah } \\
\text { menjadi sawah }\end{array}$ & $\begin{array}{c}\text { Lahan basah } \\
\text { hutan alami }\end{array}$ \\
\hline Alakang & Barringtonia acutangula & $\mathrm{x}$ & - \\
Gelam * & Eugenia sp. & $\mathrm{x}$ & $\mathrm{x}$ \\
Jaho & Terminalia bellirica & $\mathrm{x}$ & - \\
Alas Batu & Hymenachne acutigluma & $\mathrm{x}$ & - \\
Rumput Alas* & Sacciolepis sp. & $\mathrm{x}$ & - \\
Eceng Gondok & Eichhornia crassipes & $\mathrm{x}$ & $\mathrm{x}$ \\
Kapu Seratin & Salvinia molesta & $\mathrm{x}$ & - \\
Capo Air & Polygonum pulchrum & $\mathrm{x}$ & - \\
Alang-alang $*$ & Imperata cylindrica & $\mathrm{x}$ & - \\
Padi Liar & Oryza rifipogon & $\mathrm{x}$ & - \\
Bungur besar & Lagerstroemia speciosa & $\mathrm{x}$ & $\mathrm{x}$ \\
Loa & Ficus racemosa & - & $\mathrm{x}$ \\
Sengkuang & Pometia pinnata & - & $\mathrm{x}$ \\
Mangium & Acaccia mangium & $\mathrm{x}$ & - \\
Pulai & Alstonia scholaris & & $\mathrm{x}$ \\
Renghas & Gluta renghas & - & $\mathrm{x}$ \\
Nipah & Nypa fructicans & - & $\mathrm{x}$ \\
Sempur Air & Dillenia excelsa & - & $\mathrm{x}$ \\
Putat & Planchonia valida & $\mathrm{x}$ & $\mathrm{x}$ \\
Jambu Air & Eugenia aquea & - & $\mathrm{x}$ \\
Guyun Lapok & Alternanthera sessilis & $\mathrm{x}$ & - \\
Palem kipas $*$ & Livistona sp. & $\mathrm{x}$ & $\mathrm{x}$ \\
\hline Ket; & & &
\end{tabular}

Ket; x: ditemukan; -: tidak ditemukan; *: ditemukan sarang

\section{Status Lindung}

Terdapat 21 jenis burung yang dilindungi menurut PP No.7 tahun 1999 tentang pengawetan jenis tumbuhan dan satwa, 4 jenis burung termasuk appendix II menurut status perlidungan perdagangan Convention on International Trade in Endangered Species of Wild Fauna and Flora (CITES). Selain itu terdapat 42 spesies burung termasuk kategori least concern, 2 spesies burung kategori near threatened, dan 3 spesies burung kategori vulnerable menurut status perlindungan International Union for the Conservation of Nature and Natural Resources (IUCN). 


\section{KESIMPULAN}

Berdasarkan penelitian yang telah dilakukan di lahan basah Way Pegadungan dapat disimpulkan bahwa:

1. Ditemukan 56 spesies burung dengan total 1.451 individu yang berasal dari 20 famili.

2. Keanekaragaman jenis burung di pada lahan basah yang alami memiliki indeks keanekaragaman jenis 3,44 dan indeks kesemarataan sebesar 0,9, lebih tinggi dibandingkan dengan lahan basah yang telah beralih fungsi menjadi sawah 2,91 dan indeks kesemarataan sebesar 0,78. Kedua komunitas lahan basah Way Pegadungan mempunyai indeks kesamaan sebesar 0,73.

\section{DAFTAR PUSTAKA}

Bibby. C., M. Jones., dan S. Marsden. 2000. Survei Burung. Buku Hal 34-35. SMKG Mardi Yuana. Bogor.

Daget. 1976. Les Modeles Mathematicques en Ecologie. Buku Hal. 30. Masson. Paris. Perancis

Holmes, D., dan W. M. Rombang. 2001. Daerah Penting bagi Burung: Sumatera. Hal 11. PKA/BirdLife. Wetland International-Indonesia Programme. Bogor.

Mac Kinnon, J., K. Philipps, dan B. Van Balen. 2010. Seri Panduan Lapangan BurungBurung Di Sumatera, Jawa, Bali, dan Kalimantan. Buku hal.1-40. LIPI. Bogor.

Kesuma, M. I., B. S. Dewi., dan N. Nurcahyani. 2013. Keanekaragaman jenis burung di Lampung Mangrove Center Desa Margasari Kecamatan Labuhan Maringgai Kabupaten Lampung Timur.Jurnal Satek V dan Indonesia Hijau. Lembaga PenelitianUniversitas Lampung Hal 637-644.

Pergola, B., dan B. S. Dewi. 2013. Keanekaragaman Jenis Burung Di Lahan Basah Bujung Raman Desa Bujung Dewa Kecamatan Pagar Dewa Kabupaten Tulang Bawang Barat. Jurnal Satek $V$ dan Indonesia Hijau Lembaga Penelitian-Universitas Lampung Hal. 114.

Rohiyan, M., A, Setiawan., E, L, Rustiati. 2014. Keanekaragaman jenis burung di hutan pinus dan hutan campuran Muarasipongi Kabupaten Mandailing Natal Sumatera Utara. Jurnal Sylva Lestari vol. 2 Hal. 89-98.

Sulistyadi, E. 2010. Kemampuan kawasan nir-konservasi dalam melindungi kelestarian burung endemik dataran rendah Pulau Jawa studi kasus di Kabupaten Kebumen. Jurnal Biologi Indonesia. Perhimpunan Biologi Indonesia. 237-253.

Surya, D. C., W. Novarino, dan A. Arbain. 2013. Jenis-jenis burung yang memanfaatkan Eurya acuminata DC di kampus Universitas Andalas Limau Manis, Padang. Jurnal Biologi Universitas Andalas Hal. 90-95. 